\title{
Insanity in a Sea of Islands: Mobility and Mental Health in Aotearoa New Zealand's Pacific Sphere
}

\author{
JACQUELINE LECKIE
}

\begin{abstract}
This article builds upon the fragmentary historical evidence of mental illness and mental health within South Pacific societies to explore the nexus with migration and mobility. The focus is on the Pacific territories that were under Aotearoa New Zealand's jurisdiction. The article explores concepts of mental health and mobility within Pacific societies that became entangled with European concepts to designate insanity. The paper then discusses how mental illnesses were exacerbated or induced through migration and travel across the Pacific. The last section explores the transfer of mentally ill patients from some Pacific islands to Aotearoa. This article is based upon the 2018 J. D. Stout Lecture at Victoria University of Wellington.
\end{abstract}

The term insanity may appear provocative, in the context of contemporary discourse on mental health, or Pacific terms for mental wellness, such as the Samoan, soifua malöloina o le mā faufau. Crucial to this article's analysis of mental health is its reference to space: a sea of islands; the Pacific, or Oceania. ${ }^{1}$ In 1993, Professor Epeli Hau 'ofa wrote the seminal essay, "Our Sea of Islands," rejecting Eurocentric perceptions of tiny powerless islands in a distant sea, that had conferred truth and knowledge to the colonial and postcolonial masters. Hau'ofa flipped the colonial gaze of peripheral, remote islands to a standpoint within the vast ocean to offer a vision that was holistic and inclusive. ${ }^{2} \mathrm{He}$ also used the term insanity in a metaphorical sense to refer to the political craziness that Fiji embarked upon when it went down the coup pathway in $1987 .{ }^{3} \mathrm{He}$ was familiar with people's personal terror of insanity, and the incomprehension, fear, yet also care and love from families and communities throughout the Pacific. Hau'ofa was a storyteller, and some of his characters might have been considered lialia - an encompassing Fijian term that can refer to a child being silly, a drunk fool, the wandering village madman, homeless people begging in town, or a "St. Giles case" - the permanent tarnish given to severely mentally ill people committed to Fiji's psychiatric hospital, the former asylum founded in $1884 .^{4}$

This paper builds upon the fragmentary historical evidence of mental illness and mental health within South Pacific societies, ${ }^{5}$ to explore the nexus with migration and mobility. ${ }^{6}$ The focus is on the Pacific territories that New Zealand had jurisdiction over. There is still only limited awareness of New Zealand's Pacific "empire"7; there is even less awareness of the role that health links played in this. The Cook Islands, fifteen islands within a vast expanse of ocean, became a British protectorate in 1888; in 1901, along with Niue, they were annexed by New Zealand. Self-government, and a relationship of free association with New Zealand came to the Cook Islands in 1965, and to Niue in 1974. Britain annexed Tokelau islands in 1916 and transferred administration to New Zealand in 1926. Tokelau is still administered by New Zealand, and Tokelauans are New Zealand citizens. When World War One broke out, New Zealand seized control of Western Samoa (which had been a German protectorate since 1900), and from 1920 until independence in 1962 administered the territory as a mandate for the League of Nations, and then as a trust territory for the United Nations. This paper also briefly refers to other Pacific nations, such as Fiji, that Aotearoa had strong medical connections with. The first part of this article explores concepts of mental health and mobility within Pacific 
societies, where insanity became entangled with European concepts. As I have explained in my history of madness in Fiji:

Colonizing madness was not simplistically about state hegemony or controlling minds through asylum building, or lunacy legislation. It also reflected tensions and prejudices within homes, villages, workplaces and churches, and-sadly for insane destitutes - also when those communities failed. Mental despair could also be an outcome of the destruction and displacement wrought by migration and colonialism. Rather than place the incursion of colonial madness management against the extremes of either a humane civilizing mission or hegemonic social control ... the practices and discourse of modern biomedicine and mental health were articulated in local communities, as well as the asylum. ${ }^{8}$

This article then discusses how mental illness could be exacerbated or induced among migrants and travellers across the Pacific. The last section explores the transfer of mentally ill patients from some Pacific islands to Aotearoa.

\section{Pacific Insanities}

Many Pacific peoples are uncomfortable with not only the English words "insanity" or "madness," but also similar indigenous terms (see Table 1). Humour or avoidance within Pacific cultures can deal with uncomfortable issues, and deflect from publicly acknowledging or addressing the private pain of mental illness. ${ }^{9}$ But such cultural measures can lead to both the subject of mental health, and the personal suffering of individuals and their kin, being discursively and physically hidden: a silence that reinforces stigma. Although many indigenous Pacific cultures located causes of insanity within indigenous ontologies, these became entangled within Western and Christian frameworks.

European discourse and formal structures of insanity were transferred to the Pacific through colonialism and biomedicine. Europeans assumed that insanity was a product of civilization, a theory that knitted with nineteenth-century European representations that Polynesians were innocent, primitive, in harmony with nature, and unfettered by madness. Alienist Daniel H. Tuke claimed that "A South Sea Islander might be much more ignorant than the Wiltshire labourer and yet not so circumstanced that he would transgress the laws of mental health,"10 while physician Edward Jarvis declared that "Insanity is then a part of the price which we pay for civilization." 11 The Eurocentric view of mental distress presupposed Rousseau's notions of the primitive savage. Yet Europeans during the nineteenth century held contradictory views about insanity and civilization, because the incomprehensible Native was also seen as crazy. ${ }^{12}$ Pacific peoples have been variously conceived as innocent, in harmony with nature, unfettered by madness, or pathological.

Insanity may have been a new word within Pacific cultures but there had long been indigenous terms, oral traditions, concepts and treatments for mental and neurological disorders. Indigenous ontologies and practices were not static, and became entangled with the foreign: with Christianity, and later with biomedicine. An insanity lexicon within Pacific communities (Table 1) is problematic. Translation into English psychiatric terminology is subjective; terms have changed within indigenous cultures; and psychiatric nosology also changes. The meaning of words within Pacific cultures can depend upon the social context, and some words that might be spoken about "madness" are sacred and should not be shared in public. ${ }^{13}$ 
Table 1. Selected Pacific Terms Relating to Mental Illness ${ }^{14}$

\begin{tabular}{|c|c|c|c|c|}
\hline & Samoan & $\begin{array}{l}\text { Cook Islands } \\
\text { (mainly } \\
\text { Rarotongan) }\end{array}$ & Niuean & Tokelauan \\
\hline $\begin{array}{l}\text { Mad, insane, crazy, } \\
\text { foolish }\end{array}$ & $\begin{array}{l}\text { mai valea, } \\
\text { gasegase o le } \\
\text { mafaufau }^{15}\end{array}$ & $\begin{array}{l}\text { nēneva, } \\
\text { 'āuoūo }\end{array}$ & $\begin{array}{l}\text { goagoa, } \\
\text { heketia, } \\
\text { vikoia }\end{array}$ & $\begin{array}{l}\text { vale, } \\
\text { valea }\end{array}$ \\
\hline $\begin{array}{l}\text { Worry, anxiety, } \\
\text { depression }\end{array}$ & $\begin{array}{l}\text { ma'i popolé, } \\
\text { ma i manatu }\end{array}$ & maromaroā & fakakgitau & $\begin{array}{l}\text { popole, } \\
\text { fakaatu }\end{array}$ \\
\hline $\begin{array}{l}\text { Spirit/ghost } \\
\text { sickness/possession }\end{array}$ & $\begin{array}{l}\text { ma 'i äitu } \\
\text { ma 'i aiku } \\
\text { ma 'i fasa }\end{array}$ & $\begin{array}{l}\text { maki tūpāpaku, } \\
\text { maki tāpiri }\end{array}$ & $\begin{array}{l}\text { aitu, } \\
\text { fakakaikiko, } \\
\text { hūaitu }\end{array}$ & $\begin{array}{l}\text { ulufia, } \\
\text { aitu }\end{array}$ \\
\hline Psychosis & & maki tūkē & & \\
\hline Epilepsy, "fits" & ma ìmāliu & maki 'uti & & maimāliu \\
\hline
\end{tabular}

Indigenous healers were widely utilised throughout the Pacific to treat spirit possession and forms of mental illness. ${ }^{16}$ Diagnosis and treatment of mental distress depended upon connecting with the social, spiritual and ancestral worlds, through indigenous healers, to restore individual and community wellness. Foreign concepts and practices might be assimilated within indigenous medical systems. ${ }^{17}$ Most people suffering from mental health issues within Pacific communities lived and worked within their communities, and when ill, were cared for, tolerated, and treated with compassion. ${ }^{18}$ Jonathan Sadowsky's comment on colonial Nigeria applies as well to the Pacific; "madness appears to be a feature of all known human societies, but one that nevertheless has distinctive features in each." 19 As put by sociologist Andrew Scull in his survey of Madness in Civilization, madness extends beyond the medical grasp. ${ }^{20}$

\section{Wandering}

The label insane could also be given by Pacific communities to someone who was very different and transgressed cultural and gender boundaries. Siniva, the wandering "village fool" who had ghost sickness (mai 'aiku) ${ }^{21}$ in Sia Figiel's novel, Where we Once Belonged, was teased and banished from her family ('aiga) and village, and "walked, walked, walked" the streets of Apia. ${ }^{22}$ She said that her brain had been used for experiments in New Zealand. Siniva was both highly visible and was ignored; a state of not belonging that led to her suicide.

Writer Alistair Te Ariki Campbell was diagnosed with depression and was a voluntary patient at Porirua hospital during $1960 .{ }^{23}$ After Campbell was orphaned aged eight in 1933, he migrated to live in a Dunedin orphanage. ${ }^{24}$ In The Frigate Bird, Campbell uncovers how his insanity was entangled with indigenous ontology and cosmology, and the mental and social displacement as a migrant from the Pacific Islands and of Pacific descent. The book depicts the protagonist's (Campbell's) crazed journey by air and sea to Penrhyn Island (Tongareva) in the Cook Islands, that was the home of Campbell's mother, Teu. His father, John, was a Pākehā trader. Campbell's narrative is a history that entwines the indigenous with colonial and biomedical regimes; in it, his life fuses the mobility he experienced as a migrant with his mental 
turmoil. His literal and mental journeys reiterate Hau 'ofa's vision of an inclusive and connected Oceania that cross-cuts through time, space and cultures with far-reaching networks.

Insanity seems to involve extremes of movement: it conjures up being in a state of heightened or incessant movement, or equally the absence of movement-lethargy, silence, catatonia. Campbell wrote, "my movements are jerky and uncoordinated.... Lunatics have to be deliberate in their movements because of their extreme confusion. Every movement must be thought out before it's carried out." ${ }^{25}$ In Fiji, Dr. Corney wrote in 1890 of an indentured Tokelauan migrant with "extreme restlessness; purposeless moving about the house, difficult to control, sleeplessness." The woman was driven insane "through thinking of old friends," but she saw devils as the cause, in the form of other migrants from the Solomon Islands. Her illness could be located within her predicament as a migrant, but she located her mental anguish within her cosmological world and culture. Just as humans are mobile, spirits within many Pacific cultures can also be restless and can wander into the minds of the living, inflicting insanity: anthropologist Raymond Firth literally depicted madness on Tikopia as possession by a "wandering spirit." In Samoa, for example, aitu (spirits) may have been responsible for enticing people into the bush and luring them to the edge of a cliff, where the spirit pushed them. ${ }^{26}$

Wandering (in the sense of movement without a purpose) was considered odd, antisocial and sometimes dangerous, within many Pacific communities. Indigenous terms for wandering, both in a physical and mental sense, could refer to craziness or madness. In Fijian, sese has referred to "wandering about; astray; in error of the mind, foolish." 27 Sese has been translated from Samoan as "wander, do wrong, mistake, do evil," ${ }^{28}$ while fesā vali valia ' $i$ refers to wandering of the mind, and savalivali to mentally ill patients. ${ }^{29}$ Tailesa, described as a lunatic old woman, wandered aimlessly in the bush in Samoa's Aleipata District. ${ }^{30}$ In 1935, she walked into Lepa village where she was teased by a boy. She threw stones at him and he ran into a fale where Amio and her family lived. Tailesa picked up a large stone and followed the boy, so Amio grabbed a stick from underneath some mats, not knowing that the stick was a fishing spear. She attacked Tailesa with the spear, that Amio's husband pulled out, before he cleaned and bandaged the wound. The family asked Tailesa to stay but she refused. A few days later, Tailesa was found in the bush, delirious and infected with a septic wound. She died, and although Amio was charged with murder, the charges were dismissed. Tailesa may have lived in the bush by choice or because of her mental condition, but such isolation - socially or physically - carries a particularly powerful message in Polynesian societies, ${ }^{31}$ and could be a sign of mental illness, especially for women. Possibly, Tailesa had previously been banished from her village because of unacceptable behaviour, as Siniva was. Banishment from the community was extremely serious in Samoa, ${ }^{32}$ and within many other Pacific societies.

\section{Suicide, Insanity, and Mobility}

Ethnographic, historic and linguistic evidence reveals the tragedy of suicide in Pacific pasts. Cluny Macpherson and La'avasa Macpherson have suggested that there was an under-reporting of suicides committed in villages, in the bush, or at sea in Samoa. ${ }^{33}$ Suicide has been presented as a cultural response within some Pacific cultures, to avoid shame, or to avoid confrontation. ${ }^{34}$ Europeans depicted suicide among Pacific peoples as impulsive: acts of revenge, of jealousy, or to escape punishment, such as when a Samoan youth killed himself and left a letter saying that he chose suicide rather than pay a court fine. ${ }^{35}$ Unfortunately, such statements say little about the wider cultural context and how other factors could impinge on mental health. Stereotypes about the propensity of certain "races" to commit suicide equally provided simplistic explanations; such stereotypes are evident in Fiji during the girmit (indentured) era 
from 1879 to 1920, with generalisations about Indians and suicide. Although the high rates of suicide and self-harm among Girmitiyas are proven, the harsh living and work conditions on plantations, treatment by overseers, and the extreme displacement wrought by migration could induce despair for any indentured migrant. ${ }^{36}$ Suicide did not necessarily indicate insanity but could be linked with mental suffering, including severe depression and sometimes psychosis. Jimi, for example, from Solomon Islands, was an indentured labourer in Samoa. In 1894 he sailed to Fiji, but during the voyage twice attempted to jump overboard. At the Immigration Depot on Nukulau Island he tried to swim to nearby Makaluva Island, but when rescued said that he did not know what he was doing. He was admitted to the mental asylum as "dull, depressed and melancholy." "37 A sample of New Zealand Samoan records for 1921-1922 touches on the tragedies of suicide and attempted suicides among indentured labourers in Samoa:

Coolie 2100, for attempting to commit suicide was sent to gaol pending his returning to China by the next transport. ${ }^{38}$

Coolie 3878 (Mr. Roberts) pleaded guilty to attempting suicide. He was convicted and discharged.- On the day of the attempt accused had been sentenced to three months' imprisonment for threatening to kill. He understood from the interpreter that he had received five years, and rather than do that stretch he decided to end the sentence right away. ${ }^{39}$

Ah Mani, a Chinese contract labourer (No. 1158) employed by the firm of O. F. Nelson and Company, Ld., was found dead last Sunday morning, hanging to the mast of the motor boat Lili. The police were informed, and with Dr Veitch made investigations which went to show that the case was one of suicide. Deceased had been in bad health for some time. ${ }^{40}$

Yet European views about suicide and race were contradictory. Just as madness was linked as a corollary of civilisation, some nineteenth-century experts considered suicide as an index of and caused by civilization.

Self-killing is emphatically the crime of intellectual peoples. Almost unknown to savages, rare among Mohammedans, it rages among the nations most advanced in cure and refinement with a fierceness exactly proportional to their mental development. ... [T] he tendency to self-kill may almost be regarded as an index to a people's civilization. ${ }^{41}$

Reports of suicide and insanity on the high seas regularly featured in the trans-Pacific shipping news during the late nineteenth and early twentieth centuries. In 1893 the Samoa Times and South Sea Advertiser reported:

Once again we have to chronicle a suicide occurring on one of the 'Frisco mail steamers. There seems to be a gruesome rivalry between the Alameda and the Monowai as to which ship will arrive at Apia with the greater accident record. It was only the other day that we had to write the sad account of the suspicious death of one of the officers of the Alameda, as also a successful attempt at suicide by drowning from the same vessel; and now in addition to the death of her doctor on a previous trip, the Monowai adds a suicide by drowning to her record. It seems that two days after leaving Sydney, a steerage passenger named Solomon jumped off the stern rails ... whilst all the other passengers were at breakfast. ${ }^{42}$ 
Ships presented opportunities for suicides. It could be difficult to prove whether someone intentionally fell or was swept overboard. Early one morning in 1910, after the Hauroto had left Rarotonga en route to Wellington from Papeete, the ship's butcher finished cutting up meat at precisely 3.50am. He then jumped overboard. The crew noted that he had been in ill health and "seemed melancholy." 43 Merchant shipping representatives from the United Kingdom, New Zealand and Australia reported during the early twentieth century that the suicide rate onboard ships may have been almost double that onshore, and that this was especially alarming among firemen, where a "kind of heat insanity" could lead to suicide. ${ }^{44}$ Oppressive working and living conditions within confined spaces could cause severe mental distress and drive some workers towards attempting suicide. For example, in 1919, two days at sea from Rarotonga, a fireman jumped from the Moana. A lifebelt was thrown in, but he did not attempt to secure it. "The man is said to have suffered from insomnia." 45

The media highlighted the madness of despondent Europeans committing suicide on the ocean, but there were reports of indigenous people also doing this. In 1936, a woman from Manihiki threw herself into the sea on the Tapua's interisland voyage in the Cook Islands. The papers reported that this "lunatic" had relieved passengers' monotony on a becalmed ship. She was rescued. ${ }^{46}$

\section{Madness at Sea}

Michel Foucault's resurrection of the "ship of fools" from Renaissance Europe could have referred to some trans-Pacific travellers: "Confined on the ship, from which there is no escape, the madman . . . is a prisoner in the midst of what is the freest, the openest of routes."47

[T] he mad were entrusted to mariners because folly, water, and sea, as everyone "knew," had an affinity for each other. ... Some of them found pleasure and even a cure in the changing surroundings, in the isolation of being cast off, while others withdrew further, became worse, or died alone and away from their families. ${ }^{48}$

The veracity of "ships of fools" is questionable, but Foucault's text conjures up the madness at sea among Pacific voyagers for European and indigenous travellers, ship workers, and indentured migrants. Fiji's colonial secretary, Dr William MacGregor, lamented in 1884 that Fiji suffers greatly from the arrival of insane and incurable persons - migrants, travellers, workers such as seamen, indentured labourers and settlers. ${ }^{49}$ Macgregor's observation applied to many other Pacific ports, such as Apia, which was a beacon for European migrants, and the destination for several Chinese and Solomon Islands indentured labourers. Foreign travellers and settlers also sailed to the Cook Islands and, although far less often, to Niue and Tokelau.

European migration to the Pacific Islands could lead to mental breakdown, precipitated by, for example, economic disasters, illness, personal relationships, cross-cultural tensions, and substance abuse. Some Europeans fell out with the colonial hierarchy and the sensibilities of colonial society, such as John Rohde, from Germany, who lived in Apia during the late nineteenth century. He sometimes ran about the streets naked, kept people awake, hurled obscenities, and was variously labelled alcoholic, lunatic, insane, mentally deranged, a public nuisance, and eccentric. ${ }^{50}$ Even more tragic were reports of suicide, such as that of Sydney Davis, manager of the Cook Islands Trading Company, found dead in his garden in Rarotonga on Sunday morning, 28 February 1909, with a gunshot wound in his head. ${ }^{51}$ An inquiry found that he had taken his own life while in a state of temporary insanity, caused by a long and serious illness and business worries. Polynesia was free of many tropical diseases, but illness could still take a toll on the mind. In 1895, W. Nelson's body was found floating in Apia 
harbour: "Deceased had been suffering from the prevailing dengue fever, which left him in a very low condition and it is surmised that his intense sufferings caused him to become insane and commit suicide." 52 Stories such as those of Rodhe, Davis and Nelson appear to highlight the perceived unsuitability of Europeans to settle and work in the tropics. Insane or inebriate Europeans compromised colonial hegemony and the ideal of the civilised European. ${ }^{53}$ There are important questions to ask about the mental health of all migrants. Some may have suffered from mental disorders before migrating. Relocation could exacerbate poor mental health, as could the trying conditions of life and work in a new place. Angela McCarthy and Cathy Coleborne's work on insanity and migration in colonial Australia and New Zealand shows that mobility may have induced mental breakdown and suicide, especially when family and community support was lacking. ${ }^{54}$

The intention and choice of migration for many mentally challenged people within the Pacific was significantly removed from Foucault's romantic description of the "ship of fools." Moreover, ill Pacific peoples were forcibly transferred across the Pacific: notably those suffering from leprosy, ${ }^{55}$ but also the insane. In 1935, the Matai transferred a group of thirtyfive leprosy patients from the Cook Islands and Samoa to Makogai leprosarium in Fiji. ${ }^{56} \mathrm{Dr}$. Edward Pohau Ellison, the chief medical officer of the Cook Islands, had to sedate and restrain two manic and violent patients, while the ship cut across the tail of a tropical cyclone.

Suddenly there was wild yelling from the leper house, two men could be seen with brooms, with which they were hitting at someone inside. From the head of one of the men blood was streaming. Dr. Ellison rushed to his cabin for his gown and rubber gloves, and then went forward to the house. The doorway was small, and there was little room inside, and he was faced by a madman who was waving a long bloodcovered file more than two feet long, with which he had attacked three of the others. There are some things that are not to be described, and the sight of that maniac, blood streaming from broken sores on his face while he shouted and waved the file is one of them. The beds, the floor, and the walls were covered with infected blood, and the ship was lurching heavily. ${ }^{57}$

This account, titled "Madmen at Sea" was widely sensationalised in the media, but lesser known was the "forced" migration of mentally ill patients from Western Samoa, the Cook Islands, Niue and Tokelau to Aotearoa.

\section{Treatment and Transfers to Aotearoa}

Attempts to transfer patients from the Pacific Islands to mental hospitals in New Zealand began during the late nineteenth century. In 1894, Frederick Moss, the first British resident (head of government) of the Cook Islands, appealed to New Zealand to accept lunatics from the Cook Islands, but this was rejected because New Zealand's asylums were overcrowded and overseas patients could not be accepted. ${ }^{58}$ Moss had ordered a dangerous lunatic, Summers, to be confined in a wire cage in Rarotonga. Moss's successor, Resident Commissioner William Gudgeon, was more successful in arranging the transfer in 1900 of Richard Exham, former British consul, and manager of Donaldson and Edenborough, to the Auckland Mental Asylum, after an unsuccessful attempt to send Exham to Fiji. Exham, aged around forty-four, suffered from mania, and died in the Auckland asylum within three months of admission. ${ }^{59}$ Richard Augustus Donaldson, another early transfer from Rarotonga, was deported in 1908 as a dangerous lunatic and committed to the Auckland Mental Hospital. ${ }^{60}$ Donaldson, of African descent and born in Jamaica, had established "native" schools and farmed on Rarotonga and Penrhyn islands. He believed, probably correctly, that he was being persecuted by higher 
authorities within the colonial hierarchy. But he was deluded that the admiral had "sent despatches promising to take me away in the Terrible as soon as certain 400 islanders had perished in accordance with decree." 61 Instead, Donaldson was arrested by two police, armed with revolvers.

Cook Islands mental health legislation, and the provision for transfer to New Zealand, was laid out under the 1915 Cook Islands Act (that included Niue), part 21, "persons of unsound mind." Sections 574 to 589 enabled a medical officer (after 1923, the chief medical officer) to make an application to the high court for an order to commit a person to medical custody for up to six months. The order, which had to be certified by two medical officers, could be renewed. Certification was almost impossible on remote outer islands, where there might be no fully registered doctors except for Cook Islands medical practitioners, who were not recognised under the 1915 act. A "dangerous" person might be confined to the local lock-up, but they would have to endure the voyage to Rarotonga where they could be detained in the hospital (known as the sanitorium) for several months, possibly years, waiting for the court to allow a transfer to New Zealand. Once committed, a warrant could be issued for "removal" of the patient to New Zealand, because it was necessary in their own interests or for the safety of other persons. Probably the first person transferred under this act was a female Cook Islands Māori, described as "simple minded, childish, and happy," who was sent to Avondale Mental Hospital in October 1917. In 1925, the medical superintendent reported that she "works well and gives no trouble." 62

There were also some transfers of mentally ill people from Western Samoa to New Zealand. In 1918, 29-year-old Baron Paul von Rauch, an Austrian planter in Samoa who had been born in Croatia, was examined by the Medical Board of the British Military Occupation of Samoa, that found him to be of "unsound mind and a lunatic unfit to be at large. He is wild in his manner and subject to delusions, has conceived a hatred for his wife and is dangerous to both her and himself." ${ }^{63}$ Von Rauch was deported under New Zealand military custody to be handed to the commanding officer of the Auckland Military District for examination before a magistrate and commitment to the Avondale Mental Hospital. But Von Rauch went missing from the Talune after he was last seen sleeping on the steamer's deck at 3.30 a.m. on 20 March 1918, during the voyage from Apia to Vava'u. The ship was searched, and the gangway guarded when the ship berthed at Vav'au, Ha'apai, Nuku'alofa and Suva, after which it was presumed that Von Rauch had jumped overboard.

The Samoa Act 1921, section 16, part XII provided legislation for the medical custody of "Persons of Unsound Mind." The chief medical officer could secure an order from the High Court for up to six months, and then have this renewed. The court could issue a warrant for the removal of the committed person to New Zealand, if this was considered necessary, in the patient's interests or for the safety of other persons. In practice, in Samoa, most mentally disturbed people were cared for by their 'aiga, who often consulted both traditional healers (taulāsea) and medical personnel. Healers might advise patients to also consult Western medical practitioners, among whom some were equally comfortable when a healer treated patients. Mental health treatment in Samoa has embraced complementary medicine. ${ }^{64}$ But violent sufferers were usually detained, sometimes for years, at the prison at Vaimea or the prison farm at Tafaigata. Although the Samoa Mental Health Ordinance was passed in 1961, institutional care for mentally ill people removed from their families was very limited. After Western Samoa attained independence from New Zealand in 1962, arrangements for the 
transfer of mental patients to New Zealand came under an agreement between the governments of New Zealand and Western Samoa.

The Department of Island Territories administered patient transfers from Cook Islands, Niue, and Tokelau to Aotearoa. My scoping research located at least forty-five transfers between 1917 and 1968; among these, thirty-two were from the Cook Islands, twelve were from Niue, and one was from Tokelau. Most mentally ill patients from the South Pacific were admitted to Auckland Mental Hospital at Avondale (in 1960 renamed as Oakley Hospital, and in 1973 as Carrington Hospital), although a few were sent to Kingseat Hospital, south of Auckland, from the 1940s to the 1960s. The majority were male: in my sample, there were only thirteen women. Diagnostic discourse changed over time to include patients from the Pacific with manic depression insanity, epileptic insanity, delusional insanity, general paralysis of the insane, ${ }^{65}$ melancholia and mania, schizophrenia, severe depressive psychosis, and those termed "feeble minded." Almost all of these patients were certified under New Zealand's 1911 Mental Defectives Act, although a few were voluntarily admitted.

The process of transferring a patient from the islands to New Zealand was complicated, and a decision not taken lightly. Doctors in the islands usually advised that it was preferable for a patient to remain where the climate, food, language, routines and caregivers (even if these were prison warders) were familiar. A warder at Niue's prison farm, for example, could "read" a patient's mood swings and predict an attack of anger and forestall it by giving the patient a task that he enjoyed, such as climbing for pawpaws. One doctor on Niue stated that the transfer to New Zealand for a patient could provoke the risk of gross deterioration, disorientation and failure of adaptation. Transfers would be cruel, as restraint and drugs would have to be used by strangers in a strange land. Several patients from the South Pacific did not speak English. New Zealand doctors also tended to endorse keeping patients in the islands.

The decision to transfer mentally ill patients to New Zealand was also influenced by logistical difficulties. Mental health staff from New Zealand were often reluctant to take the long ocean journey that could last at least four weeks, during which time patients required almost constant care. Male staff complained that their income fell, because they lost the penal rates and overtime they earned in New Zealand. Shipping crews also objected to carrying patients who were perceived to be violent and disruptive. Such an attitude partly reflected stereotypes surrounding "madness." From the 1960s, patients began to be transferred from the Pacific Islands to Auckland via air travel, but the route could be circuitous. For example, a patient from Tokelau, escorted by medical staff, had to first sail to Apia, possibly wait there several days, and then fly to New Zealand via Nadi or American Samoa.

Aputi's story from Niue during the early 1960s indicates some of the processes involved in deciding to transfer a patient, and treatment options if they remained in their home communities. ${ }^{66}$ He was a very quiet hard-working man, but his behaviour radically changed after an infectious illness. He stopped cultivating his garden and cooperating in household activities, destroyed neighbours' property and gardens and wandered at night. Aputi feared that he would be hung in Niue's prison at Fonuakula. His condition deteriorated, and he was admitted to hospital where the doctor diagnosed depressive psychosis and prescribed chlorpromazine (Largactil). Aputi returned home, but stopped taking the anti-psychotic and sedative drug, becoming even more restless and disorientated. His diagnosis shifted to paranoid schizophrenia. Aputi located his distress within indigenous paradigms, whereby he believed his illness had been caused through having offended his ancestors. Aputi started to see devils 
who he feared would kill him. Authorities on Niue were faced with the issue of where he could be safely and securely cared for. The prison farm was not considered suitable, as there were mentally ill patients there who could be violent, but Aputi's family found it very difficult to cope with his anguish. Niue's chief medical officer sought advice from New Zealand's Division of Mental Hygiene concerning the future treatment and the possibility of transferring Aputi to a New Zealand psychiatric hospital. But this was during a period when New Zealand was very reluctant to allow such transfers, with post-war overcrowding in mental hospitals there.

Aputi's story is just one among many that illustrates how mentally disordered Pacific peoples were diagnosed and treated, often haphazardly, across the sea of islands. Correspondence flowed between colonial administrations, the Department of Islands Territories, the Department of Mental Hygiene and mental hospital superintendents in Auckland. Meanwhile, the ill person's condition, provisionally diagnosed from afar, could deteriorate, especially if confined within substandard facilities. In 1960, a female patient on Niue had to be accommodated within a partially completed morgue at Niue's hospital, as the "mental block" had been destroyed by a cyclone. By 1968, a new "mental block" was constructed-simply a wire cage with no roof. Doctors in the Pacific also became caught up in the post-war era of "modern" drug and shock therapies. ${ }^{67}$ Patients could be subjected to experimentation from doctors with limited psychiatric knowledge who were advised from New Zealand by mental health experts during an era when diagnosis was in flux. Although doctors in New Zealand enthusiastically prescribed new psychoactive medication such as Largactil, they usually only sent a very limited supply (perhaps one month) to Pacific territories. ${ }^{68}$

During the 1950s, Niue's chief medical officer used insulin shock therapy for a patient with schizophrenia, but it had little effect. This therapy was highly interventionist and dangerous, even when administered within well-equipped psychiatric facilities in developed countries. The chief medical officer still wanted this patient and others from Niue to benefit from modern psychiatric treatment. His initial request for these patients to be transferred to Fiji-where drug and shock therapy was being introduced - was declined, because the mental hospital there was severely overcrowded. ${ }^{69}$ Mental hospitals were also overcrowded in New Zealand, ${ }^{70}$ but efforts were made to transfer to there the patients from Niue, who "badly need skilled psychiatric treatment." The director of mental health informed the medical superintendent at the Auckland Mental Health Hospital that he was reluctant to accept all of the referrals from Niue. Even a request during the 1950s from Niue's resident commissioner for the transfer to New Zealand of a severely mentally and physically disabled child, Tina, who was being cared for by her grandmother, was deferred by the director of mental hygiene because Templeton Farm and Levin Farm, custodial facilities for intellectually handicapped children, had insufficient accommodation to meet the needs of children within New Zealand. The commissioner was also advised that the child's family would have to meet some of the costs of maintenance for Tina within a New Zealand institution, as the child was not a New Zealand resident. Tina's story indicates the ambiguity over the status of Niueans within New Zealand's health system, and the duty of care that the administration had towards people on Niue.

This case also points to the fragility of care for severely mentally challenged people within Pacific islands that had increasing levels of out-migration. During the post-World-War-Two era, community care began to be strained in those Pacific countries with declining populations of the "left behind." Internal migration, urban growth and waged employment, even on small islands, and certainly in centres such as Apia, ${ }^{71}$ stretched the capacity of kin to be able to care for those who were mentally challenged or socially disruptive. Changes in community support 
also had implications for repatriating patients from New Zealand to their island homes. During the $1960 \mathrm{~s}$, the director of mental health advised the country's medical superintendents that mental patients should not be repatriated to their homes in New Zealand's island territories or in Western Samoa unless they were fully recovered and capable of adapting socially without any discernible risk of relapse. Most former psychiatric patients, even if discharged from hospital as "recovered," still required ongoing community and medical support. "Recovered" patients also usually needed to maintain a medication regime and have this monitored. This was not always possible within the islands, where medication supplies were often haphazard and even when medication was available, compliance could not be assured, especially if drugs caused side effects. When former patients felt and appeared to have been restored to mental health, it was tempting to cease taking any long-term medication. One suggestion was that before repatriation, patients from New Zealand territories be trialled in employment in New Zealand, or that arrangements might have to be made in consultation with the Department of Island Territories for the patient to be domiciled more permanently in New Zealand.

The director of mental health also advised Niue's resident commissioner in 1963 that the patient, Sio, who had been in custody on the prison farm for several years, would be unlikely to benefit from modern treatment in a psychiatric facility in New Zealand. The secretary of island territories warned that if Sio escaped there could be serious results, and the New Zealand administration might be criticised for holding him on Niue. The administration was still reeling from the highly publicised murder of Niue's resident commissioner, Cecil Hector Larsen, on 17 August 1953. The convicted criminals had been three escaped prisoners, but they were not mentally ill. The murder raised questions about the ability of the island's prison authorities to control inmates and New Zealand's capacity to protect the safety of inhabitants on Niue, particularly the safety of expatriates. The murder trial also drew public scrutiny into the administration's harsh treatment of Niueans, especially of prisoners. ${ }^{72}$ Sio was considered too much of a risk to others to be returned to his village. His predicament came to the attention of Niue's Legislative Assembly in 1963, and the chief medical officer changed Sio's diagnosis from manic depression to paranoia schizophrenia. ${ }^{73}$ There were also issues about what medication was most suitable for Sio's condition and, importantly for the authorities, how to sedate him. On Niue, he was prescribed phenobarbitone tablets, but New Zealand's deputy director of mental health suggested that the anti-psychotic Largactil would be preferable. However, because sun sensitivity could be a side effect of Largactil, ${ }^{74}$ the director despatched, through the Department of Island Territories, a short supply of the anti-psychotic drug Stelazine (trifluoperazine), along with an explanatory booklet. This medication could also have considerable side effects, and it would be two to three weeks before the drug took effect. Although the deputy director of health advised that the Department of Islands Territories send monthly supplies of the drug to Niue for this patient, a regular supply of medication was dependent on shipping, weather, and other factors, such that regular supply was often uncertain, as with medical supplies throughout the Pacific Islands.

\section{Conclusion: Ongoing Issues of Migration and Mental Health}

This paper ends by drawing attention to migration and mental health in Aotearoa New Zealand's historic relationship with islands in the Pacific. As New Zealand ostensibly lessened colonial ties with Pacific territories, how did this impact upon the development of local mental health care? Full treatment of this issue remains outside the scope of my paper that has focused on New Zealand's Pacific territories before decolonisation and before the substantial waves of migration from the Pacific to Aotearoa during the 1970s. 
The general consensus that transfers of mentally ill patients to New Zealand should be a "last resort" did not solve the dilemma over the treatment and constraint of a tiny number of severely mentally ill patients on small islands. The development of mental health services in Pacific territories, towards which New Zealand had an ongoing responsibility, remained a very low priority. Mental health continued to be a difficult subject to discuss within many Pacific cultures - hardly ideal where families and communities are pivotal to care. While mental health legislation has been overhauled in some Pacific nations, mental health provision has not been a health priority within countries with limited budgets and resources, and with more pressing health matters to address, such as contagious and insect-borne diseases, that visibly affected a much greater number of people than does mental illness.

One route for mental health provision within the Pacific continues to be through the mobility of health personnel and the transfer of Western psychiatry across the sea of islands. This pattern is not new. Dr. William Macgregor, who established the Fiji asylum in 1884, had been a surgeon at Aberdeen's Royal Lunatic Asylum, and superintendent of the Mental Asylum in Mauritius. He founded the original Fiji School of Medicine that, like the Fiji School of Nursing, continues to have a key role in training medical personnel in the Pacific. ${ }^{75}$ By the late $1950 \mathrm{~s}$, a few Pacific health professionals started to have psychiatric training in Australia and Aotearoa. Tautasi Faatiga Leota, from Samoa, attended Suva Medical School from 1939, where he may have been exposed to some Western psychiatry. In 1957, he enthusiastically took a course in psychotherapy along with the Diploma of Public Health he was studying at the University of Otago. ${ }^{76}$ Ram Narayan also qualified as a doctor at Otago during the 1950s, and after returning to Fiji to practice then took postgraduate studies in psychiatry during the 1960s at Callan Park Hospital in Sydney and then at Otago. In 1973, he was appointed as the first medical superintendent of St. Giles Psychiatric Hospital in Fiji. ${ }^{77}$ Regional efforts to deal with Pacific mental health began in the 1950 s with the South Pacific Commission. ${ }^{78}$ In the twenty-first century, global mental health within the Pacific has been directed through the Pacific Islands Mental Health Network and the World Health Organisation, among other networks.

This paper's inspiration came from Epeli Hau'ofa's concept of a European discourse about the Pacific in which a sea of islands was relegated to a far-off gaze, that in practice meant that colonies were neglected and undervalued, a discourse he wanted to replace. Hau'ofa's perspective can also be applied to the lack of understanding and awareness of mental health and illness within that sea of islands; although Pacific cultures had understandings and treatments for some of the conditions that western psychiatry identifies as major illnesses. The Pacific Ocean also attracted travellers and migrants, perhaps some sailing on "ships of fools." Many migrants were indentured or shipboard workers, who through displacement and onerous working and living conditions became trapped in a world of mental despair. Migration and mental illness within the Pacific also involved a small but significant number of Pacific people with severe mental illness transferred from Samoa, Niue, the Cook Islands, and Tokelau to Aotearoa for "modern" treatment and confinement there. Hau'ofa's vision can also galvanise us to move on from the shame, stigma, silence and fear conjured by the word "insanity" to that of mental wellness and health. That future perhaps lies in the work of grassroots advocacy groups such as Youth Champs for Mental Health (YC4MH) in Fiji, Te Kainga O Paunga in the Cook Islands, Goshen Trust in Samoa, and LeVa in Aotearoa New Zealand, that call for more culturally appropriate ways to address mental health. In 2017, former Samoan head of state, Tupua Tamasese Tupuola Tufuga Efi, wrote about the "fear, instability, self-doubt, outrage and depression caused by the loss of a loved one to suicide." ${ }^{\prime 79} \mathrm{He}$ went on to say that the turbulence caused is dealt with through faith in the goodness of humanity and in the spirituality of love.

Journal of New Zealand Studies NS32 (2021), 166-182 https://doi.org/10.26686/jnzs.iNS32.6871 
Those words also apply to the turbulence and mobility of what was called insanity within our sea of islands.

${ }^{1}$ This article is based on the J. D. Stout Annual Lecture that I delivered on 14 November 2018. I am
grateful to the Stout Trust for generously appointing me as the John David Stout Fellow in 2018.
Many thanks to my colleagues at the Stout Centre for New Zealand Studies for their warmth, humour
and weekly lunches. Thanks also to the always helpful staff of Archives New Zealand (ANZ),
Morgan Tuimaleali 'ifano in Suva, Dr. George Leoo-Tuitama in Apia, Marsa Dodson for advice on the
Cook Islands, and to Dr John Cranshaw, Director of Mental Health and Addiction Services, New
Zealand, for granting me access to archival files and enabling me to publish this paper. I am grateful
also to the careful reading and comments of the anonymous reviewers.
${ }^{2}$ Epeli Hau'ofa "Our Sea of Islands," in A New Oceania. Rediscovering Our Sea of Islands,
ed. Eric Waddell, Vijay Naidu and Epeli Hau 'ofa (Suva: University of the South
Pacific/Beake House, 1993), 2-16.
${ }^{3}$ Conversations between Epeli Hau'ofa and the author.
${ }^{4}$ Jacqueline Leckie, Colonizing Madness: Asylum and Community in Fiji (Honolulu: University of
Hawai'i Press, 2020).
${ }^{5}$ See, for example, Michael Goddard, Out of Place: Madness in the Highlands of Papua New Guinea (New York: Berghahn Books, 2011); Jacqueline Leckie and Frances Hughes, "Mental Health in the Smaller Pacific States," in Mental Health in Asia and the Pacific: Historical and Comparative Perspectives, ed. Harry Minas and Milton Lewis (New York: Springer, 2017), 253-72; Leckie, Colonizing Madness; Yoram Mouchenik, "La Psychiatrie Colonial en Nouvelle-Calédonie," Journal de la Société des Océanistes 113 (2001-2002): 109-19; Graham J. Roberts, "The History of Mental Health in Papua New Guinea," in Mental Health in Asia and the Pacific: Historical and Comparative Perspectives, ed. Harry Minas and Milton Lewis (New York: Springer, 2017), 223-35.

${ }^{6}$ In 2018, I applied to the Ministry of Foreign Affairs and Trade to consult Islands Territories (IT) archival material held in ANZ, relevant to the transfer of "mental cases" from Cook Islands and Niue to New Zealand during 1917-1975. Access was denied, and I was also declined access to police and prison files for Niue, 1949-1975. Because of restrictions to sources, we still know little about the treatment of Pacific peoples in the territories for which New Zealand was responsible. However, I was kindly granted access by New Zealand's Director of Mental Health to view restricted archival files of the Ministry of Health on the condition that I would not publish specific details. Unless stated, information on New Zealand territories has been generalised and is from these restricted sources. See Barbara Brookes, "Mental Health Records: Who Controls the Past?," Archifacts (April 2015): 8-16, on the restrictions to researching mental health history in Aotearoa.

${ }^{7}$ See Katie Pickles and Catharine Coleborne, eds., New Zealand's Empire (Manchester: Manchester University Press, 2016), 127-94; Damon I. Salesa, "New Zealand's Pacific," in The New Oxford

History of New Zealand, ed. Giselle Byrnes (Melbourne: Oxford University Press, 2009), 149-72. I have excluded Nauru from this article, although New Zealand was a co-trustee, along with Australia and Britain, when Nauru was a League of Nations mandate, and a United Nations trust territory.

${ }^{8}$ Leckie, Colonizing Madness, 2-3.

${ }^{9}$ Although not concerned with mental illness, for examples of the rich literature on humour within Pacific cultures, see Niko Besnier, "Humour and Humility: Narratives of Modernity on Nukulaelae Atoll," Etnofoor 28 no. 1 (2016 ): 75-95; Elisabeth Betz and Toon van Meijl, "Humour in the Negotiations of Social Identity in the Tongan Diaspora," Etnofoor 28 no. 1 (2016 ): 111-25; Bradd Shore, "The Absurd Side of Power in Samoa," Leadership and Change in the Western Pacific: Essays Presented to Sir Raymond Firth on the Occasion of His Ninetieth Birthday, ed. Richard Feinberg and Karen Ann Watson-Gegeo (London; Atlantic Highlands, NJ: Athlone Press 1996), 142-86. 
${ }^{10}$ Daniel H. Tuke, Insanity in Ancient and Modern Life with Chapters on its Prevention, London: Macmillan, 1878), 94. Alienist was a former term for a psychiatrist or a doctor who treated the mentally ill.

${ }^{11}$ Edward Jarvis, "On the Supposed Increase in Insanity," American Journal of Insanity 8, no. 4 (1852): 363.

${ }^{12}$ Caitlin Murray, "The 'Colouring of the Psychosis': Interpreting Insanity in the Primitive Mind," Health and History 9, no. 2 (2007): 7-21.

${ }^{13}$ Marsa Dodman, personal communication, October 2018.

${ }^{14}$ For Samoan terms, see Dorothy C. Clement, "Samoan Folk Knowledge of Mental Disorders," in Cultural Conceptions of Mental Health and Therapy, ed. Anthony J. Marsella and Geoffrey M. White (Dordecht: D. Reidel Publishing, 1974), 193-213); George Bertram Milner, Samoan Dictionary (London: Oxford University Press, 1966); George Pratt, Pratt's Grammar and Dictionary of the Language (Apia: The Malua Printing Press, 1862). For Rarotongan terms, see Josephine Baddeley, "Traditional Healing Practices," in Healing Practices in the South Pacific, ed. Claire D. F. Parsons (Laie, Hawai'i: Institute for Polynesian Studies, Brigham Young University, 1985), 129-43: Marsa Dodson, personal communication; W. Arthur Whistler, "Traditional and Herbal Medicine in the Cook Islands," Journal of Ethnopharmacology 13 (1985): 239-80. For Niuean, Wolfgang B. Sperlich, Tohi Vagahau Niue = Niue Language Dictionary: Niuean-English, with English-Niuean Finderlist (Honolulu: Govt. of Niue in association with Department of Linguistics, University of Hawaii, 1997). For Tokelauan, Tokelau Dictionary (Apia: Office of Tokelau Affairs, 1986).

${ }^{15}$ A contemporary term meaning "mental illness, illness of the mind." Talanoa with Dr George LeooTuitama, Mental Health Centre, Apia, 17 March 2018.

${ }^{16}$ For accounts of healers, see, for example, Baddeley, "Traditional Healing Practices,"; Wendy E. Cowling, "Eclectic Elements in Tongan Folk Belief and Healing Practice and Motivations for Contemporary Tongan Migration," in Tongan Culture and History, ed. Phyllis Herda, John Terrell and Neil Gunson (Canberra: Department of Pacific and South Asian History, 1990), 72-92; Michael Poltorak, “"Traditional' Healers, Speaking and Motivation in Vava'u, Tonga: Explaining Syncretism and Addressing Health Policy," Oceania 80, no. 1, (2010): 1-23; Whistler "Traditional and Herbal Medicine in the Cook Islands"; Cluny Macpherson and La'avasa Macpherson, Samoan Medical Beliefs and Practice (Auckland: Auckland University Press Samoa, 1990).

${ }^{17}$ Macpherson and Macpherson, Samoan Medical Beliefs and Practice.

${ }^{18}$ Leckie, Colonizing Madness.

${ }^{19}$ Jonathan Sadowsky, Imperial Bedlam: Institutions of Madness in Colonial Southwest Nigeria (Berkeley: University of California Press, 1999), 8.

${ }^{20}$ Andrew Scull, Madness in Civilization: A Cultural History of Insanity, from the Bible to Freud, from the Madhouse to Modern Medicine (Princeton and Oxford: Princeton University Press 2015), 15. ${ }^{21}$ See Richard A. Goodman, "Some Aitu Beliefs of Modern Samoans," The Journal of the Polynesian Society 80, no. 4 (1971): 463-79.

${ }^{22}$ Sia Figiel, Where We Once Belonged (Los Angeles: Kaya Press, 1999), 179.

${ }^{23}$ See Wendy Hunter Williams, Out of Mind, Out of Sight: The Story of Porirua Hospital (Porirua: Porirua Hospital, 1987).

${ }^{24}$ Michelle Keown, Postcolonial Pacific Writing: Representations of the Body (London and New York: Routledge, 2005), 84-102; Seri Inthava Kau ikealaula Luangphinith, "Tropical Fevers: "Madness" and Colonialism in Pacific Literature," The Contemporary Pacific 16, no. 1, (Spring 2004): 59-85.

${ }^{25}$ Alistair Te Ariki Campbell, The Frigate Bird, (Auckland: Heinemann Reed, 1989), 29.

${ }^{26}$ Cluny Macpherson and La 'avasa Macpherson, "Towards an Explanation of Recent Trends in Suicide in Western Samoa," Man 22, no. 2 (1987): 310. 
${ }^{27}$ David Hazlewood, A Fijian and English and an English and Fijian Dictionary: With Examples of Common and Peculiar Modes of Expression and Uses of Words, also, Containing Brief Hints on Native Customs, Proverbs, the Native Names of Natural Productions, and Notices of the Islands of Fiji, and a Grammar of the Language, with Examples of Native Idioms, ed. James Calvert (London: S. Low, Marston, 1872), 220; Leckie, Colonizing Madness, 73-74.

${ }^{28}$ Pratt, Pratt's Grammar and Dictionary of the Language.

${ }^{29}$ Milner, Samoan Dictionary; talanoa, Leoo-Tuitama.

${ }^{30}$ Auckland Star, 21 March 1935.

${ }^{31}$ Alan Howard, "Polynesia and Micronesia in Psychiatric Perspective," Transcultural Psychiatry 16 (1979): 136

${ }^{32}$ Safua Akeli, "Cleansing Western Samoa: Leprosy Control during New Zealand Administration, 1914-1922," The Journal of Pacific History 52. no. 3, (2017): 364.

${ }^{33}$ Macpherson and Macpherson, "Towards an Explanation of Recent Trends in Suicide in Western Samoa," 305-30.

${ }^{34}$ Francis X. Hezel, "In Search of the Social Roots of Mental Pathology in Micronesia," in Contemporary Issues in Mental Health Research in the Pacific Islands, ed. Albert B. Robillard and Anthony J. Marsella (Honolulu: University of Hawaii, 1987): 12-31.

${ }^{35}$ Samoanische Zeitung, 24 February 1922, 10.

${ }^{36}$ See Brij V. Lal, "Veil of Dishonour: Sexual Jealousy and Suicide on Fiji Plantations," Journal of Pacific History 20, no. 3 (1985): 135-55: Jacqueline Leckie, “'Lost Souls': Madness, Suicide and Migration in Colonial Fiji Until 1920," in Migration, Ethnicity, and Mental Health: International Perspectives, 1840-2010, ed. Angela McCarthy and Catharine Coleborne (New York: Routledge, 2012), 123-40. On the violence of indenture, see Tracey Banivanua-Mar, Violence and Colonial Dialogue: the Australian-Pacific Indentured Labor Trade (Honolulu: University of Hawai'i Press, 2007); Vijay Naidu, The Violence of Indenture in Fiji (Suva: World University Press in association with the School of Social and Economic Development, University of the South Pacific, 1980). Between 1884 and 1916, approximately twenty-nine patients in Fiji's mental asylum were Pacific labourers from outside Fiji.

${ }^{37}$ Patient number admission record, 144, St Giles Psychiatric Hospital, Suva.

${ }^{38}$ Samoanische Zeitung, 19 March 1921, 6.

${ }^{39}$ Samoanische Zeitung, 11 June 1921, 3.

${ }^{40}$ Samoanische Zeitung, 17 November 1922, 4.

${ }^{41}$ William Mathews, "Civilization and Suicide," The North American Review 152, no. 413 (1891): 481.

${ }^{42}$ Samoa Times and South Sea Advertiser, 22 July 1893, 2.

${ }^{43}$ New Zealand Times, 26 January 1910, 1.

${ }^{44}$ Cited in Francis Steel, Oceania Under Steam: Sea Transport and the Cultures of Colonialism, c. 1870-1914 (Manchester: Manchester University Press, 2011), 83. Steel discusses the mental and physical stress on the island trading ships experienced by crew.

${ }^{45}$ New Zealand Herald, 27 March 1919, 6.

${ }^{46}$ Pacific Islands Monthly, 19 August 1936, 55,

${ }^{47}$ Michel Foucault, Madness and Civilization: A History of Insanity in the Age of Reason, trans.

Richard Howard (New York: Vintage Books, 1988), 11.

${ }^{48}$ Jose Barchilon's introduction in Foucault, Madness and Civilization, iv.

${ }^{49}$ Colonial Secretariat Office (CSO) Minute Paper (MP) 84/86, 21 April 1886.

${ }^{50}$ Samoa Times and South Sea Advertiser, 19 May 1894, 2; Samoa Times and South Sea Advertiser, 4 May 1889, 3.

${ }^{51}$ New Zealand Herald, 13 March 1909, 6.

${ }^{52}$ Samoa Weekly Herald, 12 January 1895, 2.

${ }^{53}$ Richard Eves, "Going Troppo: Images of White Savagery, Degeneration and Race in Turn-of-theCentury Colonial Fictions of the Pacific," History and Anthropology 11, no. 2 (1999): 351-85;

Richard C. Keller, "Madness and Colonization: Psychiatry in the British and French Empires 18001962," Journal of Social History 35, no. 2 (2001): 298-99.

Journal of New Zealand Studies NS32 (2021), 166-182 https://doi.org/10.26686/jnzs.iNS32.6871 
${ }^{54}$ Catharine Coleborne, Insanity, Identity and Empire: Immigrants and Institutional Confinement in Australia and New Zealand, 1873-1910 (Manchester: Manchester University Press, 2015); Angela McCarthy, Migration, Ethnicity and Madness. New Zealand, 1860-1910 (Dunedin: Otago University Press, 2015); Angela McCarthy and Catharine Coleborne, "Introduction: Mental Health, Migration and Ethnicity," in Migration, Ethnicity and Mental Health: International Perspectives, 1840-2010, ed. Angela McCarthy and Catharine Coleborne (New York: Routledge, 2012), 1-14.

${ }^{55}$ See Jane Buckingham and Vicki Luker, eds., "Leprosy in the Pacific," special issue, Journal of Pacific History 52, no. 3 (2017).

${ }^{56}$ Evening Post, 29 March 1935.

${ }^{57}$ Evening Post, 29 March 1935, 8.

${ }^{58}$ ANZ, R24761219-ACGO-8333- IA1-655/ [19]-1894/134, "8 January 1894 Subject: Asking if arrangements can be made for the reception of lunatics from the Cook Islands."

${ }^{59}$ ANZ, R23703727-AAAR-17298-W480-Box 197; COR 1900/866, "Coroner's inquests - Case files - Auckland - Exham, Richard."

${ }^{60}$ Feilding Star, 14 July 1908. Donaldson died in Auckland Mental Hospital, 19 January 1920, aged 70 years. "Coroner's inquests - Case files - Auckland - Donaldson, Richard Augustus," ANZ, R23801776-ACGS-16231-J46 611- COR1920/207.

${ }^{61}$ New Zealand Herald, 13 July 1908, 4.

${ }^{62}$ Confidential sources.

${ }^{63}$ ANZ, R121100648-22525-AABK, "Colonel Robert Logan, Administrator of Samoa to

Commanding Officer, Auckland Military District, 18 March 1918"; Samoanische Zeitung, 13 April

1918, 3 .

${ }^{64}$ Goodman, "Some Aitu Beliefs of Modern Samoans."

${ }^{65}$ See "Missing or Misdiagnosed? General Paralysis of the Insane, Yaws, and Syphilis in Fiji, 18841940," The Journal of Pacific History 55, no. 1, (2020): 37-57.

${ }^{66}$ A pseudonym. Details have been generalised to preserve anonymity.

${ }^{67}$ Jacqueline Leckie, "Discourses and Technologies of Mental Health in Post-War Fiji," in The Defining Years, Pacific Islands, 1945-65, ed. Brij V. Lal (Canberra: Australian National University, 2005), 151-73.

${ }^{68}$ ANZ, R20960876-ADBZ-16163-H11096/ 30/28/38, "Mental Health - Mental Health Patients Overseas, 1925-1969."

${ }^{69}$ Leckie, Colonizing Madness, 160.

${ }^{70}$ See Warwick Brunton and Peter McGeorge, "Grafting and Crafting New Zealand's Mental Health

Policy," in Mental Health in Asia and the Pacific: Historical and Comparative Perspectives, ed.

Harry Minas and Milton Lewis (New York: Springer, 2017), 276.

${ }^{71}$ Noted on 4 July 1968, Mental Health Report, Department of Health, Dr. Tupua Tamasese and Jeff

N. Clanon (US Peace Corps), 12, Derek Freeman papers Mss. 522, Box 81, Folder 10, Special

Collections and Archives, University California San Diego).

${ }^{72}$ Dick Scott, Would A Good Man Die? Niue Island, New Zealand and the Late Mr Larsen,

(Auckland: Hodder and Stoughton, 1993). Scott argues that the three men were regarded as heroes by many Niueans because Larsen was considered a bully.

${ }^{73}$ ANZ, R14639268-ACGA-8280-W2439-IT1W2439-41-84/8/10/4, "Niue Island - Medical - Reports 018/1960 - 12/1963." Sio is a pseudonym.

${ }^{74}$ In fact, Largactil was widely prescribed in Fiji and other Pacific territories where there was extensive exposure to sun.

${ }^{75}$ Margaret W. Guthrie, Misi Utu: Dr. D. W. Hoodless and the Development of Medical Education in the South Pacific (Suva: Institute of Pacific Studies, University of the South Pacific with the South Pacific Social Sciences Association, 1979). In 1928 the school became the Central Medical School. 76 "Health - SMPs [Samoan medical practitioners] case 1955-1959," ANZ, R15386087-ACFX-8293W1510-IT-A2, box 15/GH 8/2.

${ }^{77}$ Ranjana Narayan, personal communication, 2018. 
${ }^{78}$ Jacqueline Leckie, "The 'Magic Bullets' of Mental Health in the Pacific after World War II," in "Health and Labour after the Pacific War: Pacific Islanders, Medical Infrastructure and Decolonization," ed. A. Widmer and C. Winter, special issue, Health and History (forthcoming).

${ }^{79}$ Tui Atua Tupua Tamasese Ta 'isi Efi, "Foreword," in The Relational Self: Decolonising Personhood in the Pacific, ed. Upolu Lumā Vaai and Unaisi Nabobo-Baba (Suva: University of the South Pacific Press, Pacific Theological College, 2017), xiii. 